\title{
JOURNAL.RU
}

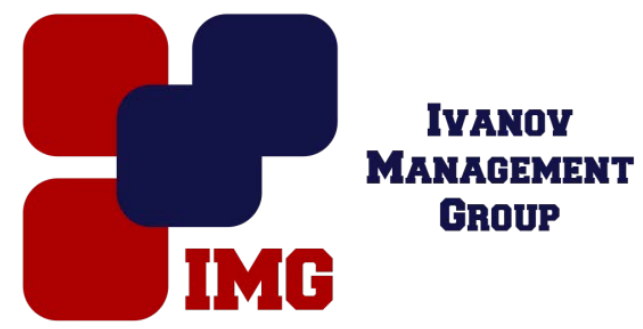

Салаватова А.M. Нижневартовский государственный университет Нижневартовск, Россия

doi: 10.18411/lj-28-02-2017-4-06

idsp 000001:lj-28-02-2017-4-06

\section{Этнокультурная направленность образования: сущность и понятие}

\section{Аннотация}

В статье рассматриваются вопросы этнокультурной направленности образования. Знание ценностей и закономерностей народного творчества важно для формирования этического и эстетического сознания. Умение ценить и понимать народное искусство есть необходимый элемент общей культуры человека, осознающего свою духовную связь с народом.

Ключевые слова: этнокультурное образование, этнокультура, народная педагогика, образование, этнос, этнопедагогизация, этнопедагогика, духовнонравственные ценности.

В современном мире необходимо сочетание общегосударственных интересов и прав граждан, сохранение своей этнокультурной, языковой и религиозной принадлежности.

Проблемы образования различных народностей, проживающих на территории России, волнуют отечественных педагогов уже длительное время.

Важную роль в воспитании и обучении играет этнокультурная проблематика. Это обусловлено несколькими причинами. С одной стороны, это набравшая силу положительная тенденция восстановления связей в осмыслении духовной истории народов, населяющих Россию. С другой стороны, играет роль внешний фактор возрастания межнациональной напряженности в современном мире, в связи с чем, усиливается поиск путей противостояния этой опасной тенденции. В-третьих, имеет значение фактор развития системы наук, исследующих этническую тематику: этнология, этнография этнолингвистика, этнопсихология, этнокультурология, этносоциология, этнопедагогика [5, с. 25].

В связи с этим наблюдается и дефицит духовных ценностей, который может быть снят именно тем духовным потенциалом, который имеется в народной педагогике. [3, с. 79]. 
Знание ценностей и закономерностей народного творчества важно для формирования этического и эстетического сознания. Умение ценить и понимать народное искусство есть необходимый элемент общей культуры человека, осознающего свою духовную связь с народом.

Фундаментальные исследования по вопросам народной педагогики представлены именами академиков РАО Г.Н. Волкова, А.Э. Измайлова, профессоров А.Ш. Гашимова, В.И. Элашвили, Я.И. Ханбикова, А.Ф. Афанасьева и других представителей разных народов.

К проблемам этнопедагогики обратились уже в середине XX веков такие этнографы, педагоги, как Г.С. Виноградов, Г.Н. Волков, В.Ф. Афанасьев, А.Э. Измайлов, С.М. Малиновская и другие.

Особую роль в процессе появления этнокультурной направленности образования сыграли исследования великого русского педагога К.Д. Ушинского. В его работах «О народности в общественном воспитании», «О нравственном элементе в русском воспитании», «Вопросы о народных школах», «Родное слово» и других получили свое развитие проблемы образования народной педагогики, национальной школы, как русской, так и других народов России.

В России термин «народная педагогика» впервые употребил именно К.Д. Ушинский. Он отметил, что общей системы воспитания всех народов не может существовать ни в теории, ни на практике. У каждого народа есть своя собственная национальная система воспитания: «Воспитание, если оно не хочет быть бессильным, должно быть народным» [6, с.55].

Народной педагогике, опирающейся на житейскую мудрость, на «обыкновенный здравый смысл» [4,c 23], в работах А.С. Макаренко уделяется особое внимание.

Содержание образования «народной школы», по Макаренко А.С., должно обязательно включать в себя национальную мудрость - народные пословицы, поговорки, народные праздники, традиции, обряды.

Идеи народной педагогики оформил в самостоятельную науку этнопедагогику Волков Г.Н. Он по праву считается основоположником этнопедагогики как науки. Волков Г.Н. дал четкое разграничение понятий «народная педагогика» и «этнопедагогика». «Если народная педагогика имеет отношение к опыту и его описанию, средствам и идеям народного воспитания, то этнопедагогика - сфера теоретической мысли, сфера науки» [2].

Содержательной основой этнокультурного образования является этнокультура. По мнению Афанасьевой А.Б., этнокультура - совокупность традиционных ценностей, отношений и поведенческих особенностей, воплощенных в материальной, духовной, социальной жизнедеятельности этноса, сложившихся в прошлом, развивающихся в исторической социодинамике и постоянно обогащающих этнической спецификой культуру в различных формах самореализации людей. Этнокультурное образование представляет собой целостный процесс изучения и практического освоения этнокультурного наследия, становление и воспитание личности на традициях культуры этноса, 
сочетающих моноэтническую глубину постижения родной культуры и полиэтническую широту [1, с.35].

Этнокультурная направленность образования на первый план выдвигает систему духовно-нравственных ценностей и идеалов личности как главную цель и результат образовательного процесса. При этом, требования к уровню знаний, умений и навыков учащихся не снижаются и их освоение происходит в ценностном контексте, выстраиваемом на материале народной культуры, с учетом реальных потребностей, интересов, а также проблем личности учащихся.

Этнокультурная направленность образования дает расширенный, углубленный курс знаний, в том числе через элементы краеведения, интегрирует и систематизирует разрозненные представления учащихся о быте, традициях, исторических событиях региона, готовит учащихся к более глубокому осмыслению философско-культурного пространства.

Этнокультурная направленность образования в наиболее полной мере может быть реализована в школах с этнокультурным содержанием образования. Школа и ее инновационный тип выступает как важнейший институт сохранения и развития этнической культуры, формирования национального самосознания, освоения детьми и молодежью ценностей родной, общероссийской и мировой культур.

В качестве основных задач этнокультурного образования выдвигаются:

- воспитание поликультурной личности: создание условий для идентификации личности со своей исконной культурой и усвоения других культур. Ориентация на диалог культур, их взаимообогащение;

- формирование многоязычного индивида: подготовка граждан, способных эффективно общаться на родном и государственном языках.

Важнейшая задача образования состоит в том, что молодому поколению должна передаваться стройная система ценностей, где на шкале иерархии одна из важнейших позиций должна быть отдана ценностям этнического единения, которая подразумевает диалектику общего и особенного, органическое единство интересов общего и этнического характера, только и способного гарантировать эффективное развитие общества как единство многообразного.

Цель этнокультурной направленности образования - удовлетворение этнокультурных образовательных потребностей малочисленных народов Севера, формирование и корреляция этнокультурной самоидентификации обучающихся, подготовка их к жизни, как в традиционном, так и современном социуме.

Содержание этнокультурного образования, отраженное в учебных планах, программах, учебных пособиях, хрестоматиях, справочной и методической литературе во многом пытается интегрировать историю и культуру Югорского края, традиционный образ жизни и возможность адаптации к цивилизованному обществу. Такая интеграция имеет задачу компенсировать потери духовного богатства, накопленного народами Севера в ходе многовековой истории освоения и развития совей территории. Содержание обучения и воспитания народов ханты 
и манси лишь в некоторой степени отражает опыт традиционной жизни этносов, влияющий на стиль мышления, миропонимания, этнопедагогические идеалы.

Стремление народов сохранить свою самобытность, подчеркнуть уникальность своей культуры, изменение ценностных идеалов в обществе и обращение в образовании к потенциалу этнической культуры привело к тому, что современное образование требует формирования у учащихся умений и навыков овладения этническим и мировым культурным наследием, влияющим на становление личности современного человека в полиэтническом социуме. В современном образовании важную роль в воспитании и обучении играет этнокультурологическая проблематика. Критерий успешности воспитания не может считаться оправданным и рациональным только на ценностях одной культуры, приоритете одной культуры в ущерб другим.

Исходя из выше изложенного, дадим определение: Этнокультурная направленность образования - это образование, в основе которого лежит отнесение личности к определенной этнической общности, образование, направленное на сохранение этнокультурной идентичности личности путем приобщения к родному языку и культуре с одновременным освоением ценностей мировой культуры.

Этнокультурная направленность образования представляет собой сложное социально-педагогическое явление. Оно базируется на фундаментальных основах народной педагогики, теории этноса, этнопсихологии, философии, культурологии, социально-культурной деятельности и других пограничных отраслей научного знания. Содержащийся в нем региональный этнокультурный образовательный компонент может и должен рассматриваться как необходимый структурный элемент подготовки бакалавров педагогики к профессиональной деятельности.

Процесс этнокультурного образования способствует формированию чувства любви к отечественной культуре в балансе с пониманием и уважением к культурам других народов, что является условием толерантных отношений в межэтнических контактах, необходимых в современном полиэтническом обществе.

Этнокультурная направленность образования способствует обогащению современного педагогического опыта. Сегодня ни одно образовательное учреждение не обходится без мероприятий, посвященных фольклорным праздникам народов России. В педагогических традициях народа обучение и воспитание осуществляется в гармоничном единстве.

В условиях современного этапа развития российского общества возрастает роль науки и образования как факторов межрегиональной и межэтнической интеграции, что особенно актуально в Ханты-Мансийском автономном округе Югре, с ее сложным этническим составом населения. Очевидно, что за долгий период интенсивного взаимодействия культур, этносов, цивилизаций здесь накоплен богатый опыт интеграции, вписывания европейских по генезису моделей науки и образования в региональный социокультурный контекст. Одним из факторов межэтнической интеграции выступает российская система образования, 
которая является основным носителем идей о человеке, обществе, мире, основной формой существования систем ценностей.

Именно образованный человек причастен к исторической и культурной традиции. Он ощущает принадлежность к определенной общности и народу, у него сформированы культурные потребности: стремление к нравственности, осмысленной деятельности, красоте, высшим духовным началам.

Изучение этнокультурных явлений является важной сферой проявления эмоций и психических состояний, необходимым условием, способствующим позитивному развитию этнокультурного образования. Большая роль в этой связи принадлежит учебным заведениям, т.к. важнейшим транслятором национальной и мировой культуры является школа. Она призвана осуществлять общее образования и воспитывать уважительное отношение к инонациональным культурным ценностям. Именно в рамках школьного учебного процесса происходит приобретение и усвоение растущим человеком системы духовных и культурных ценностей, приобщение к национальным культурам, обрядам, верованиям, характерным для того или иного этноса, видам традиционного промысла, быта, стереотипам поведения. Поэтому многие исследователи (педагоги, психологи, социологи) определяют этнокультурное содержание образования как приоритетное составляющее для современной школы.

\section{Литература}

1. Афанасьева А.Б. Совершенствование этнокультурного образования современных педагогов // Человек и образование. №4. 2008. С. 34-38.

2. Волков Г.Н. Этнопедагогика. /Под ред. И.Т. Огородникова. - Чебоксары: Чувашское книжное издательство, 1974. - $376 \mathrm{c}$.

3. Ибрагимова Л.А., Салаватова А.М. Этнокультурный компонент в деятельности современных школ региона //Вестник Нижнев. гос. ун-та. Серия Психологические и педагогические науки. - Вып.4 /Отв. ред. И.П. Истомина. - Нижневартовск: Изд-во Нижнев. гос. ун-та, -2013. - С.79-83.

4. Макаренко А.С. Собрание сочинений: В 6 т. М., 1978. Т. 2. 422 с.

5. Петрова Г.А. Формирование этнопедагогической культуры педагога в образовательном процессе вуза //Обучение, воспитание, развитие учащейся молодежи в условиях поликультурного пространства России: Материалы Всероссийской научнопрактической конференции - Нижневартовск: НГГУ, 2008. - С.25-26.

6. Ушинский К.Д. О народности в общественном воспитании // Избранные педагогические сочинения. Т. 1-2 / Под ред. А.И. Пискунова. - М.: Педагогика, 1974. Т. 1 C. 51-123. 